\title{
中职院校对学生日常管理现状的问题分析及对策
}

徐小军

DOI:10.32629/jief.v1i1.345

[摘 要] 中职院校学生日常管理是学校最重视也是最头疼的问题, 本文针对中职院校学生的管理工作中存在的问题进行了 分析和研究, 传统的管理办法已经不能满足当代学生的管理要求了, 我们必须把传统的管理办法进行革新、利用新时代下 的管理方法来进行改革, 可以使得中职学校学生的全方面得到健康发展。

[关键词] 中职院校; 问题及分析; 管理工作

学生的日常管理工作无论是对学校还是学生个人都具 有非常重要的意义。学生日常管理是学校管理工作的重要 组成部分。我国社会的不断发展, 教育领域的不断发展, 需要的人才也从单一转变为综合人才的需求。综合素质人 才需要拥有的素质比过去多了很多。这些素质要求与中职 各院校的教育管理模式是不可分开的, 那么, 如何提高对 中职院校学生的管理成为当前最重要的课题。

\section{1 学生日常管理工作存在的问题}

\section{1 学校管理制度与管理体系不够完善}

由于中职院校的学生基础理论知识较差, 导致中职院 校在教学上存在较大的困难, 而且学生不遵守学校的各项 规定, 给中职院校的管理带来较大的困难。中职院校的管 理模式偏向于各自为政, 没有形成良好的管理要求。每一 位教师的管理模式也存在一定程度上的差异, 有些教师为 了应付学校给的任务, 只是被动的进行了管理。学生的日 常管理工作最终是要落实到班主任头上的, 但是像迟到、 旷课等违反学校规章制度的行为, 班主任一般都是通过对 学生引导、找学生谈话等方式来解决。而从日常的管理经 验来看, 这种方式往往达不到良好的效果。

\section{2 学校管理组织运营方式不当}

学校管理组织方面存在的问题主要体现在以下几个方 面: 一是形式主义, 没有具体到人和事。二是现在的老师 和管理职能部门的担当不够。我国传统为师者为为父, 要 求严格教育学生, 但是在当前的社会背景和教育的追责上 导致老师不敢管, 管不严, 严了学生出问题怕担责任, 丢 饭碗, 这是实际问题, 包含了我们教育者的无奈。中职院 校的管理方法还存在着不合理的问题, 学校要落实管理教 育的时候, 却没有进行正面的教育内容, 忽略了教育模式 的有效性与时效性, 从而使得学生也没有得到挣的理解人 生价值观和道德品质。班级主任老师在进行管理的时候, 也没有起到监管的作用, 发现问题直接推向学校或者找其 他原因。对管理的措施也存在着问题。

\section{3 学校管理人员队伍质量有待提高}

管理的主要实施对象就是我们的老师, 所以老师综合 素质的高低, 直接决定着学生管理的质量。在这个问题点上, 学校必须要建立起来高品质的师资管理队伍, 班主任教师 作为班级管理第一主要负责人物, 是参与管理的第一人, 必须使得班主任教师的综合素质得到有效提高, 才能在管 理制度上有一个质的飞跃与提高。学校管理人员包括所有 参与学生日常管理的人, 不仅是学校领导和班主任, 其余 的老师、学生会干部也要参与到学生的日常管理中。但是 在中职院校中很多教师都认为, 学生日常管理应该是班主 任和学生处管理人员的事, 与自身没有直接的关系。所以, 学校在选择班主任教师的时候, 必须要选择责任心强的教 师来担任, 参与到管理的第一线管理中去。与此同时, 学 校也要转变学生的观念, 学会鼓励学生, 让学生也参与到 管理中来, 把学生干部、学生会、其余老师的作用充分发 挥体现出来。学生的思想教育是重中之重。所以学校还要 建设好教师队伍, 使得正确的思想传递给我们的学生们。

\section{2 学生日常管理工作问题原因分析}

\section{1 缺少明确的管理细则}

随着教育改革的深入进行, 也给学生日常管理工作带 来了较大的困难。素质教育的目的是为了提升学生的能力 和综合素质, 促进学生的成长和发展。而学生日常管理工 作中存在的问题将会阻碍素质教育的发展。很多教师都不 明确自身所应该承担的责任, 在工作和管理过程中缺乏统 一的规章制度, 这也为中职学校学生工作的开展造成了很 大的阻碍。在实际管理的过程中学校与教师所采取的方式 都很被动, 仅仅是被动的对现代的学生们进行各种管理, 缺没有真正调动起学生的积极态度, 也不能发挥学生的主 动性, 当不能够重视起来学生的自我管控的时候, 这种管 理模式就失去的自己的作用。虽然在短时间内可以解决学 生的问题, 但是对于学生自身以及未来的发展来看缺没有 任何的帮助, 属于较为低水平的管理方式。

\section{2 学生生源的水平}

中职院校学生日常管理工作还受市场经济以及网络的 影响。互联网的普及给学生日常管理带来了新的问题。在 
网络时代下, 学生将面临更多的诱惑。部分学生的自控能 力和自律能力较差, 容易沉溺于网络中。导致学生的水平 也参差不齐。当学生的生源、学生特点不一的时候也加大 了学生的管理工作难度。当前中职院校的学生生源差异较 大、学生之间存在较大的贫富差异, 并且独生子女的数量 较多, 学生的个性比较鲜明, 自我意识都很强。在这样的 情况下, 学生出现心理问题就会增多, 大大增加了教师学 生管理工作的难度。并且现在的学生也会由于个性过于自 我, 出现逆反的状态, 这就使得管理工作难以开展下午, 不近影响了学校学生管理的水平, 也影响了中职院校的正 常教学

\section{3 加强学生日常管理工作的具体策略}

\section{1 做好班级管理工作，改善学生管理理念}

学生来到新环境, 面对新的老师, 在心理上会存在一 定的惧怕感, 趁这个机会班主任要开始实行班规让学生知 道班主任是时刻在关注着他们。学生作为学校的猪蹄, 学 校管理者应将有利于学生发展的各种思想与活动贯彻到学 校内部管理中, 制定高效的、人性化的管理制度模式。班 主任要在学生和家长面前树立信任感。再一个就是要对学 生进行德育和人生价值观的教育, 做好学生人生的领路人, 给学生做思想工作。帮助学生树立正确的人生观、价值观, 提升学生的道德水平和综合素质, 这样才能更好地完成学 生管理工作。让学生逐渐认同管理制度, 自觉把班级和学 校当前自己的家, 增加学生集体荣誉感。只有注重学生的 学习、身心、德智体美等方面和谐发展, 一切以管理以学 生健康发展为中心, 做到人性化教育。真正实现想学生所 想的科学管理体制。

\section{2 加强对学生性格、身心等方面管理}

由于中职学生缺乏正确的价值观和行为准则, 学生对 教师的批评和表扬常常会不知所措。这就需要教师在学生 日常管理工作中有较大的耐心。职教学校不仅仅要在学术 上对学生进行投资, 同时也要给学生提供良好的学习环境,
引导学生建立社团等兴趣。培养学生的自我规划、自我组 织能力, 实现学生的自我管控, 弥补学校管理的不足之处。 并且可以从以下几个反面来做: 一是多表扬学生, 引导学 生多展现自己的优势, 对只有经常表扬学生, 让学生感受 到教师的认可, 才能进一步提升学生的自信心, 使学生自 觉遵守班级规定, 在学生管理工作中积极配合。二是适当 的给学生施加压力, 避免因个人行为给班级造成影响。三 是增加和学生的交流, 为此, 教师需要增加和学生之间的 交流沟通, 了解学生的心理状态, 对于学生在学习或生活 中存在的问题要及时处理。

\section{4 结语}

学生日常管理作为学校管理工作中的重要组成部分, 做好学生的日常管理工作是非常重要的。中职院校中的学 生管理还是存在着很多的问题, 人才的培养需要学校的有 效管理, 只有把上述问题中的所有问题利用有效的办法得 到解决, 才能使得学生各方面得到提升, 学校必须要改善 制度、完善制度, 利用各种活动来促进学生的管理工作, 最终让学生的管理工作落到实处。

\section{[参考文献]}

[1] 自我教育与他人教育的互动分析 [J]. 郑国庆 . 经济 研究导刊 .2014(01):11.

[2] 中国职业教育发展与改革 : 经验与规律 [J]. 姜大 源 . 职业技术教育 .2011(19):20.

[3] 自我教育的概念界定及特征分析 [J]. 冯春芳. 前 沿 .2004(03):15.

[4] 高职院校学生日常管理工作探析 [J]. 周芳琳. 湖北 函授大学学报 .2016(20):11-13.

[5] 浅谈学生日常管理实施 [J]. 李宗山, 张建军. 黑龙 江科技信息 .2013(05):9. 